\title{
PERSEPSI MASYARAKAT TERHADAP POSITIONING KOTA TEBING TINGGI
}

\author{
Zulfi Pandapotan Nasution \\ Universitas Sumatera Utara \\ zulfipandapotannasution@yahoo.co.id
}

\begin{abstract}
Abstrak
Tujuan penelitian ini adalah untuk mengetahui persepsi masyarakat terhadap positioning Kota Tebing Tinggi, kemudian mengetahui potensi unggulan yang dapat menjadi positioning Kota Tebing Tinggi. Penelitian ini menggunakan paradigma interpretif. Informan penelitian ini adalah masyarakat yang terdiri dari stakeholders Kota Tebing Tinggi yang diambil dengan metode purposif. Metode yang digunakan adalah metode deskriptif kualitatif yang pengumpulan datanya dilakukan melalui FGD (Focused Group Discussion), wawancara dan studi dokumen. Analisis data dilakukan dengan mencatat seluruh informasi yang didapatkan dari informan, kemudian melakukan interpretasi. Hasil penelitian menunjukkan bahwa persepsi masyarakat terhadap positioning Kota Tebing Tinggi adalah kota jasa, tetapi jasa tersebut harus dispesifikasikan pada jasa tertentu. Selanjutnya, potensi unggulan yang dapat menjadi positioning Kota Tebing Tinggi adalah kuliner (lemang dan roti kacang). Berdasarkan persepsi masyarakat dan potensi unggulan, maka positioning Kota Tebing Tinggi adalah kota jasa wisata kuliner.
\end{abstract}

Kata Kunci : persepsi, positioning, Kota Tebing Tinggi

\begin{abstract}
The purpose of this research is to determine the public perception of Tebing Tinggi city positioning, to find out the potential of Tebing Tinggi positioning. This research used interpretif paradigm. The informants are people consisting of stakeholders of Tebing Tinggi city taken with purposive method. The method used is descriptive qualitative with focused group discussion (FGD), interview and document study. Data was analyzed by recording of all information obtained from informants and then interpreting. Result of the study shows that the public perception of positioning Tebing Tinggi city as a city of services, but the service must be specified at certain services. Then the excellent potential can be used for positioning Tebing Tinggi city is culinary (lemang and roti kacang). Based on the public perception and excellent potential, Tebing Tinggi city positioning is as a city of culinary and tourism services.
\end{abstract}

Keywords : perception, positioning, Tebing Tinggi city

\section{PENDAHULUAN}

Positioning didefinisikan sebagai seni dan ilmu yang berhubungan dengan produk atau jasa melalui salah satu atau beberapa segmen pasar yang bertujuan untuk menetapkan makna yang berbeda dari pesaing (Belch \& Belch, 2001:52). Kasali (2000:49) mengatakan positioning pada dasarnya adalah suatu strategi untuk

\begin{abstract}
memasuki jendela otak konsumen. Positioning biasanya tidak menjadi masalah dan tidak dianggap penting selama barangbarang yang tersedia dalam suatu masyarakat tidak begitu banyak, dan persaingan belum menjadi sesuatu yang penting. Positioning baru akan menjadi
\end{abstract}


penting bilamana persaingan sudah sangat sengit.

Positioning merupakan hal yang penting dalam konsep komunikasi, khususnya dalam komunikasi pemasaran. Hubungan positioning dan komunikasi terlihat ketika positioning akan melahirkan pernyataan (statement), dimana pernyataan tersebut akan disampaikan kepada masyarakat sebagai sasaran pasar. Sebagaimana yang dikatakan Kasali (2000:534-535) bahwa pernyataan positioning berhubungan erat dengan strategi komunikasi. Pernyataan positioning harus bisa mewakili citra yang hendak dicetak dalam benak konsumen. Kata - kata diolah dalam bentuk suatu rangkaian kalimat yang menarik yang disampaikan dengan manis. Pernyataan yang dihasilkan harus cukup singkat, mudah diulang - ulang dalam iklan atau dalam bentuk - bentuk promosi lainnya, dan harus memiliki dampak yang kuat di sasaran pasar.

Sejalan dengan itu, globalisasi telah menciptakan persaingan. Hamdi (1998), dalam Nawar, Sirojuzilam \& Suriadi (2006:57) mengatakan bahwa era globalisasi dan perdagangan bebas telah menyebabkan saling keterkaitan dan ketergantungan dan menimbulkan persaingan global yang semakin berat. Untuk itu pemerintah daerah harus bergerak cepat dalam menentukan positioning daerahnya. Mengingat persaingan mempromosikan dan memasarkan daerah, saat ini dan masa mendatang tidak lagi pada persaingan tingkat nasional tetapi sudah sampai pada tingkat internasional.

Situs Kementerian Dalam Negeri Republik Indonesia menguraikan bahwa di era globalisasi saat ini, daerah harus saling berebut satu sama lain dalam mencari perhatian (attention), pengaruh (influence), pasar (market), tujuan bisnis \& investasi (business \& investment destination), turis (tourist), tempat tinggal (residents), orang - orang berbakat (talents), dan kegiatan (events). Pemerintah daerah harus membangun brand (brand building) untuk daerahnya, tentu yang sesuai dengan potensi maupun positioning yang menjadi target daerah tersebut. Sebuah daerah harus memiliki karakteristik khusus yang bisa dijelaskan dan diidentifikasikan. Misalnya tampak fisik kota, pengalaman orang terhadap daerah tersebut, dan penduduk seperti apa yang tinggal di daerah tersebut (http://www.kemendagri.go.id/article/2013/0 4/12/city-branding-untuk-pemda-perlukah).

Menurut Kartajaya dan Yuswoady (2005) dalam Helmi (2007:120) positioning daerah pada hakikatnya adalah sebuah janji yang diberikan oleh daerah. Ketika Singapura megganti positioning-nya dari "The New Asia" menjadi "Uniquely Singapore" maka apa yang ditawarkan oleh negara ini harus benar-benar unik yang tidak ditemukan oleh negara manapun.

Positioning daerah dilakukan untuk mengomunikasikan merek (brand) atau ciri khas daerah dalam rangka untuk menarik minat para wisatawan untuk berkunjung dan singgah. Menurut Grabow (1998) dalam Yananda \& Salamah (2014:185) bahwa kemampuan mengkomunikasikan sebuah kota adalah persyaratan penting dalam sebuah fase pemasaran kota yang berhasil.

Oleh karena itu dalam membangun positioning daerah harus dirumuskan dengan hal-hal yang unik sebagai diferensiasi dalam persaingan. Wardhani (2011:187) menyatkan bahwa strategi komunikasi pemasaran daerah dilakukan oleh pemerintah daerah yang harus mampu menciptakan penawaran yang dibutuhkan pasar. Produk/jasa yang ditawarkan dalam hal ini adalah potensi daerah yang mampu diserap oleh pasar atau diminati investor. Pemerintah daerah harus berupaya melakukan diferensiasi produknya menjadi produk yang memiliki keunikan dan kekhasan dari daerahnya tersebut. Hal inilah 
yang sebenarnya mengharuskan setiap daerah untuk melakukan positioning sehingga mampu untuk melihat tingkat persaingan terhadap produk yang ditawarkannya.

Begitu pentingnya positioning daerah dilakukan untuk menghadapi persaingan, maka positioning sebuah kota harus dapat memperlihatkan identitas kotanya kepada trader, tourits, investor, talent, developer, organizer. Itulah mengapa setiap kota harus memiliki identitas kota. Anholt (dalam Yananda \& Salamah, 2014:69) menekankan pada identitas kompetitif (competitive identity), dimana titik tekannya pada evaluasi brand kota dengan menggunakan enam brand kota. Pengukuran brand kota yang disusun Anholt ini dikenal dengan nama Anholt-GMI City Brand Index. Indeks ini merupakan instrumen untuk mengevaluasi efektivitas aktivitas branding yang terdiri dari 6 (enam) aspek, yaitu :

1. Presence (seberapa akrab orang mengenal dengan kota tersebut).

2. Place (aspek fisik dari kota, yaitu seberapa cantik dan menyenangkan atau sebaliknya kota tersebut).

3. Potential (kesempatan yang ditawarkan oleh kota, misalnya terkait aktivitas ekonomi dan pendidikan).

4. Pulse (Keberadaan gaya hidup perkotaan yang vibrant atau ketiadaannya bagaimana kota menggairahkan).

5. People (Populasi lokal dalam hal keterbukaan, kehangatan dan masalah keamanan).

6. Prerequisites (kualitas hidup dasar yaitu standar dan harga akomodasi dan kelengkapan publik).

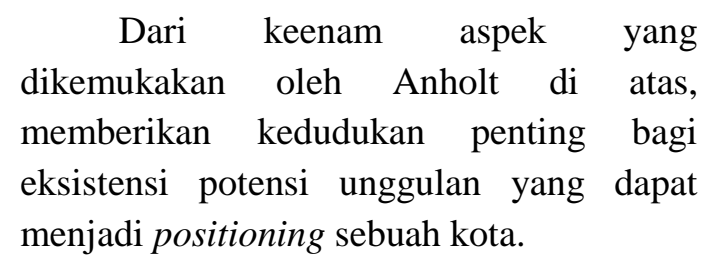

Positioning daerah yang tepat akan memberikan peluang untuk kemajuan pembangunan di daerah tersebut. Tentu saja kemajuan tersebut disebabkan adanya daya tarik masyarakat setempat dan masyarakat pendatang (wisatawan) baik domestik maupun mancanegara untuk berkunjung atau singgah ke daerah yang memiliki positioning. Oleh karena itu positioning daerah harus mengandung unsur - unsur potensi yang dimiliki daerah tersebut, dimana perumusan konsep positioning daerah harus melihat persepsi berbagai elemen masyarakat. Sebagaimana Ries \& Trout (2002:13) mengatakan intisari pemikiran positioning adalah menerima persepsi sebagai realitas dan kemudian merestrukturisasi persepsi- persepsi tersebut untuk menciptakan posisi yang diinginkan.

Kemudian Fill (2002) dalam Olson \& Sandru (2006:4) mengatakan keberhasilan positioning dilihat dari proses informasi sebuah produk yang dikomunikasikan dan dipersepsikan oleh konsumen dan stakeholder (pemangku kepentingan) sehingga dapat dibedakan dan menempati pemikiran konsumen dan stakeholders.

Lubis (2012:62) menjelaskan secara luas tentang definisi persepsi adalah proses dimana kita mempertahankan hubungan dengan dunia di lingkungan kita, karena kita biasanya mampu mendengar, melihat, mencium, menyentuh dan merasa. Kita dapat merasakan lingkungan kita, kita dapat menyadari apa yang terjadi di luar kita. Sebenarnya apa yang kita lakukan adalah menciptakan citra dari segi fisik dan objek sosial serta peristiwa yang kita temukan dalam lingkungan.

Persepsi tidak dapat dipisahkan dari hal- hal yang penting. Hal - hal yang penting ini menurut Mulyana (2007:191) adalah sesuatu yang menjadi aturan pokok atau prinsip dari persepsi yang terbentuk berdasarkan pengalaman dan pembelajaran masa lalu, selektifitas rangsangan indrawi 
yang muncul, berdasarkan dugaan, berdasarkan evaluasi, berdasarkan konteks.

Mempersepsikan sebuah kota tentu berhubungan bagaimana kita menggambarkan kota tersebut dalam benak kita. Selain melihat pendapat Mulyana dalam pembentukan persepsi diatas, kajian penelitian persepsi masyarakat ini juga mengambil pandangan Yananda \& Salamah (2014:89) dalam menentukan citra kota merupakan gambaran yang ada dibenak kita tentang sebuah kota. Gambaran ini merupakan akumulasi dari pengetahuan, pengalaman dan keterpaparan (exposure). Pengetahuan tentang kota berasal dari media massa, buku, hasil penelitian, foto dan juga percakapan dengan orang lain. Pengalaman dan keterpaparan merupakan hasil interaksi kita dengan kota.

Selanjutnya Kartajaya (2007:14) secara mendalam menjelaskan ada 4 (empat) hal yang harus dilakukan untuk membangun positioning, yaitu :

1. Positioning harus dipersepsikan secara positif oleh pelanggan dan menjadi reason to buy mereka. Oleh karena positioning mendeskripsikan value yang unggul, positioning menjadi penentu penting bagi pelanggan pada saat memutuskan untuk membeli.

2. Positioning seharusnya mencerminkan kekuatan dan keunggulan kompetitif perusahaan. Jangan sekali - kali anda merumuskan positioning, tetapi ternyata tidak mampu melakukannya. Hal ini bisa over-promise under-deliver, pelanggan akan mengecap anda telah berbohong.

3. Positioning harus bersifat unik sehingga dapat dengan mudah mendiferensiasikan diri dari para pesaing. Keuntungan yang diperoleh dari positioning yang unik adalah bahwa positioning akan tidak mudah ditiru oleh pesaing. Konsekuensi dari kondisi ini adalah positioning tersebut akan bisa sustainable dalam jangka panjang.

4. Positioning harus berkelanjutan dan selalu relevan dengan berbagai perubahan dalam lingkungan bisnis. Jika positioning sudah tidak relevan dengan kondisi lingkungan bisnis, dengan cepat anda harus mengubahnya melalui repositioning.

Positioning kota yang diangkat dalam penelitian ini adalah positioning Kota Tebing Tinggi. Alasan peneliti memilih Kota Tebing Tinggi sebagai lokasi penelitian karena posisi strategis Kota Tebing Tinggi, sebagaimana yang dijelaskan dalam Rencana Pembangunan Jangka Menengah Daerah (RPJMD) Kota Tebing Tinggi Tahun 2011- 2016. Pertama, letak Kota Tebing Tinggi berada pada jaringan jalan lintas Sumatera dan merupakan titik pertemuan jaringan lintas tengah dan lintas timur Sumatera serta jaringan jalan utama (arteri) yang menghubungkan Kota Medan dengan Kota Turis Parapat (Danau Toba) serta jaringan kereta api Medan-Rantau Prapat dan Medan-Siantar. Kedua, kehadiran Bandara Kuala Namu dan ketersediaan jalan akses tol bandara Tebing Tinggi-Kuala Namu akan berdampak pada pembangunan dan pengembangan Kota Tebing Tinggi. Ketiga, Pelabuhan Internasional Kuala Tanjung dan kawasan industri Sei Mangke akan memberikan peluang dalam pembangunan kota dan perekonomian daerah Kota Tebing Tinggi (Perda Kota Tebing Tinggi, 2012:Bab IV-1).

Ketiga poin alasan diatas yang diperoleh dari dokumen RPJMD Kota Tebing Tinggi 2011-2016 merupakan Program Masterplan Percepatan dan Perluasan Pembangunan Ekonomi Indonesia (MP3EI) di Provinsi Sumatera Utara. Rencana pelaksanaan program MP3EI di atas, secara otomatis akan menjadikan posisi 
Kota Tebing Tinggi sebagai posisi central dari program itu. Sebagimana tertulis dalam dokumen RPJMD Kota Tebing Tinggi Tahun 2011-2016 (Perda Kota Tebing Tinggi, 2012:Bab V-14) menyatakan bahwa Kota Tebing Tinggi berada di lokasi strategis titik sentral segi tiga emas.

Selanjutnya RPJMD Kota Tebing Tinggi Tahun 2011-2016 (Perda Kota Tebing Tinggi, 2012:Bab V- 5 \& Bab VI20) menjelaskan bahwa misi dari Kota Tebing Tinggi poin keempat adalah melanjutkan pembangunan Kota Tebing Tinggi sebagai kota jasa yang memiliki produktivitas, inovasi, kreativitas, dengan berorientasi pada pemberdayaan ekonomi kerakyatan. Dimana strategi dan arah kebijakan untuk mewujudkan misi poin keempat adalah dengan merencanakan dan melaksanakan kawasan pergudangan dan kawasan industri yang berada dekat dengan akses jalan tol dan merealisasikan pembangunan terminal peti kemas dalam mengantisipasi terwujudnya jalan tol Medan-Kuala Namu-Tebing Tinggi.

Kemudian dalam RPJMD Kota

Tebing Tinggi Tahun 2011-2016 (Perda Kota Tebing Tinggi, 2012:Bab IX-2-3) menjelaskan bahwa tahap percepatan promosi dan akselerasi pertumbuhan ekonomi tahun 2015 adalah Tebing Tinggi sebagai kota jasa yang memiliki daya saing melalui kegiatan perdagangan dan jasa, wisata budaya dan wisata kuliner. Pada tahap selanjutnya dikemukakan tahap pembangunan kota tahun 2016 merupakan tahapan perwujudan Kota Tebing Tinggi sebagai kota jasa yang berdaya saing, nyaman, peduli dan sejahtera. Pada tahap pembangunan ini Kota Tebing Tinggi menjadi pusat jasa dan perdagangan serta industri yang maju dan modern, pusat seni dan budaya serta kepariwisataan yang berkembang.

Secara realita kondisi alam yang dimiliki Kota Tebing Tinggi tidak menjadikannya sebagai daerah yang memiliki peluang sebagai daerah tujuan wisata. Namun harus diakui posisi Kota Tebing Tinggi merupakan kota yang berada pada jalur perlintasan efektif dari Medan dan Bandara Internasional Kuala Namu menuju daerah wisata Danau Toba-Parapat serta memiliki dampak yang signifikan dari program MP3EI dengan pembangunan jalan tol sebagaimana telah diuraikan sebelumnya sehingga memberikan peluang besar bagi Kota Tebing Tinggi untuk berkembang menjadi kota maju.

Keberadaan positioning suatu daerah akan mengundang wisatawan untuk berkunjung atau singgah di daerah tersebut. Wisatawan yang berkunjung atau singgah di suatu daerah, tentu akan berdampak pada pemasukan/ penerimaan keuangan bagi daerah yang terangkum dalam dokumen Pendapatan Asli Daerah (PAD).

Berdasarkan uraian di atas, promosi dan pemasaran daerah akan menciptakan persaingan di setiap daerah. Masing-masing daerah akan melakukan persiapan dan perencanaan yang baik dalam mempromosikan potensi daerahnya. Bagi daerah yang tidak siap bersaing, maka akan tertinggal dari daerah yang memang benarbenar siap untuk bersaing dalam mempromosikan dan memasarkan daerahnya.

Menurut Porter (2000) dalam Santoso (2010:1), pada hakekatnya kemampuan daya saing suatu wilayah adalah produktivitas, dimana produktivitas menjadi penentu utama standar hidup suatu wilayah dalam jangka panjang. Salah satu unsur penting yang mendukung produktivitas perusahaan menurut Porter adalah lokasi geografis. Oleh karena posisi lokasi geografis Kota Tebing Tinggi yang strategis sebagaimana telah dijelaskan pada paragraf - paragraf di atas menjadikannya sebagai kota yang memiliki peluang dan mampu berdaya saing. Posisi geografis yang strategis dimiliki Kota 
Tebing Tinggi tentu akan menjadi sumber kekuatan untuk bersaing dengan daerahdaerah sekitarnya. Dari penjelasan di atas, penelitian ini akan berfokus pada persepsi masyarakat terhadap positioning Kota Tebing Tinggi.

Adapun yang menjadi fokus masalah dalam penelitian ini adalah 1) Bagaimana persepsi masyarakat terhadap positioning Kota Tebing Tinggi?, dan 2) Potensi unggulan apa yang dapat menjadi positioning Kota Tebing Tinggi?

\section{METODOLOGI PENELITIAN}

Penelitian ini menggunakan metode studi deskriptif kualitatif berupa kata-kata tertulis atau lisan dari informan dengan paradigma interpretif. Menurut Gunawan (2013:56- 57) teori interpretatif ditujukan memahami pengalaman hidup manusia, atau menginterpretasikan makna-makna. Dalam penentuan informan, peneliti menggunakan teknik purposif. Dimana subjek penelitian ini adalah masyarakat yang merupakan stakeholders Kota Tebing Tinggi yang terdiri dari pengunjung, pemerintah, media, penduduk dan pekerja, tokoh masyarakat, bisnis dan industri, dan akademisi.

Pengumpulan awal data pada penelitian ini menggunakan metode Focus Group Discussion (FGD). Sebagaimana Yananda \& Salamah (2014:112) mengatakan bahwa metode yang selalu digunakan dalam mengevaluasi citra kota dari perspektif pemangku kepentingan kota adalah melalui kelompok diskusi terarah atau focus group discussion (FGD). Pada tahap selanjutnya pengumpulan data dilakukan melalui wawancara. Wawancara dilakukan jika ada informan yang tidak hadir pada kegiatan FGD. Kemudian pengumpulan data pada penelitian ini juga menggunakan metode studi dokumen.
Metode analisis data penelitian ini dilakukan dengan cara mencatat seluruh informasi yang diperoleh dari FGD, wawancara dan studi dokumen, kemudian melakukan interpretasi dan mengembangkan berdasarkan teori dari permasalahan yang sedang diteliti. Dan untuk selanjutnya peneliti menyajikannya secara deskriptif kualitatif. Analisis ini didasarkan pada pendapat Seiddel (1998) dalam Moleong (2006:248) yang mengatakan bahwa proses analisis data kualitatif dapat dilakukan dengan cara, yaitu; 1) mencatat dan menghasilkan catatan lapangan; 2). mengumpulkan, mengklasifikasikan dan membuat ikhtisar; 3). berpikir, dengan jalan membuat agar data tersebut memiliki makna.

\section{HASIL DAN PEMBAHASAN}

\section{Persepsi Masyarakat Terhadap Positioning Kota Tebing Tinggi}

Berdasarkan hasil FGD, wawancara dan studi dokumen diperoleh data bahwa pada umumnya para informan mempersepsikan positioning Kota Tebing Tinggi adalah kota jasa. Persepsi tersebut didasarkan kepada beberapa hal diantaranya adalah sebagai berikut :

1. Tebing Tinggi Sebagai Kota Jasa

Rata-rata informan mengetahui Tebing Tinggi sebagai kota jasa diperoleh dari membaca dan mendengar visi misi Pemerintah Kota Tebing Tinggi pada masa kepemimpinan Abdul Hafiz Hasibuan (Walikota Tebing Tinggi Periode $2000 \mathrm{~s} / \mathrm{d}$ 2005 dan 2005 s/d 2010). Hasil temuan tersebut menunjukkan bahwa persepsi informan dalam melihat citra Kota Tebing Tinggi sesuai dengan penjelasan Yananda \& Salamah (2014) bahwa gambaran citra kota diakumulasi dari pengetahuan seseorang yang berasal dari media massa, buku, hasil 
penelitian dan percakapan dengan orang lain.

Pada sisi lain ada juga informan yang mengetahui Tebing Tinggi sebagai kota jasa diperoleh dari pengalaman dan interaksinya dengan Kota Tebing Tinggi yang meliputi sejarah dan posisinya yang strategis berada di titik pertemuan dan perpisahan lintas timur dan lintas barat Sumatera. Menurut Wikantiyoso (2006) dalam Amar (2009:56) aspek historis dan pengenalan "image" yang diitangkap oleh warga kota menjadi penting dalam pemaknaan identitas kota atau citra kawasan.

Demikian halnya dengan pendapat Vincent (1997:35) yang mengatakan faktor yang mempengaruhi persepsi seseorang adalah pengalaman masa lalu karena manusia biasanya akan menarik kesimpulan yang sama dengan apa yang ia lihat, dengar dan rasakan. Begitu juga Mulyana (2007) mengatakan bahwa persepsi sesorang kepada sebuah objek dibentuk oleh pengalaman dan pembelajaran masa lalu. Sejalan dengan hal tersebut Yananda \& Salamah (2014:89) mengatakan dalam menentukan gambaran citra kota juga dilihat dari pengalaman dan keterpaparan dalam berinteraksi dengan kota tersebut.

\section{Realisasi Tebing Tinggi Sebagai Kota Jasa}

Untuk merealisasikan Tebing Tinggi sebagai kota jasa sebagaimana dalam RPJMD Kota Tebing Tinggi yang meliputi pergudangan, perindustrian, terminal peti kemas, wisata budaya dan wisata kuliner. Para informan lebih dominan mengatakan wisata kuliner dapat direalisasikan bahkan menurut mereka wisata kuliner adalah jasa yang dapat direalisasikan dengan cepat.

Beberapa alasan mereka mengatakan wisata kuliner dapat direalisasikan, karena posisi Kota Tebing Tinggi yang berada di perlintasan wilayah timur dan barat, kemudian kota perlintasan efektif menuju daerah objek wisata Danau Toba Parapat Kabupaten Simalungun. Hal ini sesuai dengan pendapat BPS Kota Tebing Tinggi (2014) bahwa Tebing Tinggi terletak pada jalur lintas utama Sumatera, merupakan titik pertemuan jaringan lintas timur dan lintas tengah Provinsi Sumatera Utara serta jaringan jalan utama (arteri) yang menghubungkan Kota Medan dengan Kota Turis Parapat (Danau Toba) serta jaringan kereta api yang menghubungkan Medan dengan Kisaran-Tanjung Balai-Rantau Prapat dan Medan dengan Pematang Siantar.

Ada catatan penting saat FGD bahwa Gul Bakhri Siregar (Kepala Bappeda Kota Tebing Tinggi) mengatakan untuk terminal peti kemas yang direncanakan lokasinya sesuai RTRW (Rencana Tata Ruang Wilayah) Kota Tebing Tinggi adalah di areal tanah PT. KAI Tebing Tinggi ternyata sulit direalisasikan karena PT. KAI berada di bawah naungan pusat dalam hal ini Kementerian BUMN. Posisi Kota Tebing Tinggi dapat mewujudkan Tebing Tinggi sebagai kota wisata kuliner dengan cepat. Namun dalam kajian teori perencanaan positioning Kota Tebing Tinggi adalah kota layak huni, berikut kutipan pendapat beliau :

"Untuk realisasi kota jasa, sebenarnya terminal peti kemas itu diarahkan lokasinya kalau menurut RTRW Kota Tebing Tinggi ada di lahan stasiun kereta api. Persoalannya PT. KAI adalah instansi pusat yang berada di bawah BUMN sehingga disitu kadang kendalanya dan agak repot juga. Jadi akibat dari itulah makanya agak sulit untuk mewujudkannya. Kalau wisata budaya dengan melakukan penataan tempat - tempat bersejarah di Tebing Tinggi besar peluangnya. Kalau wisata kuliner tengah berlangsunglah sekarang ini di Tebing Tinggi, orang yang lewat singgah, orang sekitarnya menjadikan tempat jajanan malam. Berdasarkan posisinya Kota Tebing Tinggi sudah bisa menjalankan statusnya sebagai kota jasa yang 
backgroundnya yang wisata kuliner itu tetapi kalau wisata budaya belum sepenuhnya masih diperlukan upaya upaya untuk ke situ. Artinya wisata kuliner dapat direalisasikan dengan cepat itu pun sesuai dengan perkembangan pasar. Secara teori perencanaan untuk berdomisili maka positioning Tebing Tinggi adalah kota layak huni”.

Selain itu menurut informan yang lain mengatakan keterbatasan lahan Kota Tebing Tinggi menyebabkan sulitnya untuk merealisasikan jasa lainnya. Sebagaimana yang tertuang dalam RPJMD Kota Tebing Tinggi seperti pergudangan dan industri, seperti yang diungkapkan Suriadi (Kepala KP2T Kota Tebing Tinggi) di forum FGD berikut ini :

"Permohonan pembangunan telah banyak diajukan, tetapi lahan yang tersedia sangat minim. Realisasi Tebing Tinggi sebagai kota jasa dan perdagangan apabila ada lahan yang luas".

Persepsi informan di atas sesuai dengan teori prosesing informasi yang dikembangkan oleh Bettman (1978), yang menjelaskan bahwa perilaku manusia dimulai dengan kesadaran rasional mengenai lingkungannya. Pengetahuan terhadap lingkungannya itu diperoleh seseorang melalui panca inderanya (mata, telinga, hidung, kulit dan lidah) atau dalam bahasa Inggris disebut sense, sehingga prosesnya disebut sensasi. Oleh karena itu, manusia berpikir (cognitions) dalam otaknya untuk menerima informasi dari proses sensasi ini (Kasali, 2000:522).

Menurut Lubis (2012:62) bahwa persepsi adalah proses dimana kita mempertahankan hubungan dengan dunia di lingkungan kita, karena kita biasanya mampu mendengar, melihat, mencium, menyentuh dan merasa. Kita dapat merasakan lingkungan kita, kita dapat menyadari apa yang terjadi di luar kita.

\section{Sosialisasi Tebing Tinggi Sebagai Kota Jasa}

Sosialisasi Pemerintah Kota Tebing Tinggi yang menyatakan Tebing Tinggi Sebagai Kota Jasa dari data hasil temuan menunjukkan bahwa sebagian informan menyatakan Pemerintah Kota Tebing Tinggi telah mensosialisasikan Tebing Tinggi sebagai kota jasa dan di antara jawaban mereka ada yang mengatakan sosialisasi telah dilakukan tetapi belum maksimal, sebagaimana pendapat Abdul Khalik (Wartawan Harian Waspada Tebing Tinggi) saat wawancara mengatakan :

"Tebing Tinggi sebagai kota jasa di masa Pak Hafiz Hasibuan pernah disosialisasikan tetapi tidak maksimal, mungkin karena spesifikasi kota jasa itu tidak jelas".

Persepsi informan tersebut dapat dikatakan memiliki hubungan dengan teori disonansi kognitif karena teori ini menjelaskan bahwa orang memperhatikan informasi dalam lingkungannya yang sesuai dengan sikap dan keyakinannya dan sementara tidak akan menghiraukan informasi yang tidak konsisten (West \& Turner, 2008:142).

Disonansi (ketidaksesuaian) konsep kota jasa dengan realita terhadap arah spesifikasi jasa yang belum jelas menjadikan informan mempersepsikan sosialisasi belum dilaksanakan secara maksimal. Menurut Mulyana (2007) persepsi ini dibentuk dari pengalaman. Kemudian sejalan dengan pendapat sebelumnya, Yananda \& Salamah (2014) juga mengatakan persepsi dalam melihat citra kota diakumulasi dari keterpaparan seseorang kepada kota tersebut.

Dari penelusuran di Kota Tebing Tinggi, peneliti menemukan tulisan "Tebing 
Tinggi Kota Jasa dan Perdagangan” di gapura Sri Mersing Lapangan Merdeka Kota Tebing Tinggi. Peneliti menemukan pernyataan Tebing Tinggi sebagai kota jasa hanya di lokasi tersebut dan keberadaanya tidak mudah terbaca oleh orang lain. Hal tersebut menunjukkan bahwa sosialisasi Tebing Tinggi sebagai kota jasa sudah dilaksanakan Pemerintah Kota Tebing Tinggi namun terkesan belum maksimal. Tulisan yang menyatakan "Tebing Tinggi Kota Jasa Dan Perdagangan” terlihat kecil dan sering tertutup gerobak pedagang yang berjualan di lokasi tersebut, sehingga keberadaannya jarang diketahui oleh masyarakat Kota Tebing Tinggi atau pun pengunjung yang datang ke Kota Tebing Tinggi.

\section{Presence atau keberadaan orang mengenal Kota Tebing Tinggi}

Umumnya informan mengatakan bahwa orang mengenal Kota Tebing Tinggi karena lemang dan roti kacangnya, seperti pendapat Agung Bimantoro (Mahasiswa STIE Bina Karya Tebing Tinggi) saat FGD :

"Saya yakin Tebing Tinggi ini dikenal orang, seperti rekan - rekan kerja saya yang ada di Inalum mereka sering cari makanan atau mau kuliner pasti ke Tebing Tinggi meskipun mereka adalah orang Sergai, Simalungun dan Batubara. Saya yakin orang luar kenal dengan Tebing Tinggi ini, mereka kenal dengan lemangnya. Artinya mereka kenal kota ini dengan ciri khas kotanya".

Kemudian Azhar Efendi Lubis (Kepala Diporabudpar Kota Tebing Tinggi) dalam pers releasenya mengatakan bahwa Tebing Tinggi adalah kota lemang (http://sumutpos.co/lemang-besar-96-rasaakan-disuguhkan-untuk-masyarakat/).

Teori penilaian sosial (social judgement theory) yang disusun oleh Muzafer Sherif memperkirakan bagaimana seseorang menilai suatu pesan dan penilaian yang dibuat dapat mempengaruhi sistem kepercayaan yang sudah dimiliki sebelumnya. Teori penilaian sosial menyatakan bahwa latitude of acceptance (wilayah penerimaan) dimana suatu argumen yang masuk dalam wilayah penerimaan akan lebih mampu membujuk dibandingkan dengan argumen yang berada di luar wilayah penerimaan (Morissan, 2013:82).

Penjelasan teori penilaian sosial tersebut memiliki hubungan dengan persepsi informan bagaimana orang lain mengenal Tebing Tinggi, dimana umumnya orang mengenal Tebing Tinggi dengan lemang dan roti kacangnya kemudian kota pertemuan lintas timur dan lintas barat serta perlintasan menuju daerah wisata parapat. Teori tersebut mengatakan bahwa kehidupan sosial, acuan atau referensi tersimpan di dalam kepala kita serta berdasarkan pengalaman sebelumnya. Kita mengandalkan pada referensi internal atau disebut reference point. Hal ini juga dikuatkan oleh Vincent (1997:35) bahwa persepsi dipengaruhi oleh pengalaman dari teman - teman, dimana mereka menceritakan pengalaman yang telah dialaminya.

Bila dihubungkan dengan penelitian Saragih (2013:174) yang mengatakan bahwa image atau citra yang terbangun dari potensi Kota Binjai adalah dikenal dengan Kota Rambutan. Sama halnya dengan image atau citra Kota Tebing Tinggi dimana potensi yang dikenal orang terhadap Kota Tebing Tinggi ada pada kuliner lemangnya. Tentu ini merupakan ciri khas daerah yang telah lama ada di Tebing Tinggi meskipun menurut beberapa informan kualitas lemang Tebing Tinggi harus ditingkatkan agar memiliki daya tarik wisatawan.

Dari uraian di atas, persepsi informan umumnya menyatakan positioning Kota Tebing Tinggi adalah kota jasa, kemudian beberapa informan menyarankan agar kota jasa tersebut dikhususkan pada jasa-jasa 
tertentu sehingga memiliki arah yang jelas. Seperti dinamika diskusi yang terjadi dalam forum FGD, dimana Kartini (Kabid Budaya \& Pariwisata Disporabudpar) mengatakan :

"Untuk sementara positioning kota Tebing Tinggi ini adalah kota lemang, roti kacang kemudian nanti kita mau buat soto Tebing Tinggi. Jadi saya katakan positioning Tebing Tinggi ini bisa diarahkan kepada kota jasa wisata kuliner".

Kemudian M. Hidayatullah Sinaga (Leisure Tourits) dalam penjelasan yang sama juga mengatakan positioning Kota Tebing Tinggi adalah kota jasa.

"Saya katakan positioning Tebing Tinggi dapat dikatakan sebagai kota jasa karena semua unsur - unsur itu ada mulai dari industri, pergudangan, dan kuliner. Bahkan mungkin dari yang lain menurut pendapat saya seperti jasa pendidikan dan jasa kesehatan. Dari hal - hal itu, maka positioning Kota Tebing Tinggi bisa sebagai kota jasa”.

Meskipun demikian, informan yang lain Bahtiar Gultasno (Busines Tourits) di forum FGD memiliki persepsi yang berbeda terhadap positioning Kota Tebing Tinggi. Beliau mengatakan :

"Saya setuju supaya kota lemang karena itu bukan sesuatu yang dibuat sebagai brand tapi memang sudah menucul dengan sendirinya tanpa dibuat, tinggal bagaimana pemerintah mengembangkannya misalnya kemasannya. Belum pernah tahu Tebing Tinggi disosialisasikan sebagai kota jasa, baru FGD ini saya tahu. Saya mengusulkan positioning Tebing Tinggi adalah kota lemang, karena positioning harus ada karakter daerah".

Persepsi mereka sangat dipengaruhi dan dibentuk dari proses pengalaman, pengetahuan dan keterpaparan (exposure) mereka dengan Kota Tebing Tinggi. Konsensus persepsi para informan terhadap positioning Kota Tebing Tinggi akan memberikan keberhasilan dan kesuksesan positioning Kota Tebing Tinggi, sebagaimana Fill (2002) dalam Olson \& Sandru (2006:4) mengatakan keberhasilan positioning dilihat dari proses informasi sebuah produk yang dikomunikasikan dan dipersepsikan oleh konsumen dan stakeholder (pemangku kepentingan) sehingga dapat dibedakan dan menempati pemikiran konsumen atau stakeholders. Dari pendapat tersebut terlihat jelas bahwa persepsi sangat berperan dalam melihat positioning suatu merek.

Hal ini sesuai dengan apa yang dikatakan Myers (1996) dalam Kasali (2000:522) bahwa persepsi merupakan suatu proses untuk mengartikan sensasi dengan memberi gambar-gambar dan asosiasi di dalam memori untuk menafsirkan dunia di luar dirinya.

Tebing Tinggi sebagai kota jasa dan perdagangan merupakan visi jangka panjang Kota Tebing Tinggi selama 20 tahun ke depan yang ditetapkan dalam Rencana Pembangunan Jangka Panjang Daerah (RPJPD) Kota Tebing Tinggi (Perda Kota Tebing Tinggi, 2006:3). Pada tahun 2013 pertumbuhan ekonomi Kota Tebing Tinggi mencapai $6,91 \%$. Pertumbuhan tersebut meningkat dibandingkan tahun 2012 yang tumbuh sebesar 6,75\%. Pertumbuhan ekonomi yang paling cepat di sektor perdagangan, hotel dan restoran yang mencapai 8,15\% (BPS Kota Tebing Tinggi, 2014:260). Hal ini memperlihatkan kondisi perkembangan ekonomi Tebing Tinggi sebagai kota jasa dan perdagangan.

\section{b. Potensi Unggulan Yang Dapat Menjadi Positioning Kota Tebing Tinggi}

Potensi sebuah kota merupakan modal yang digunakan untuk mempromosikan dan 
memasarkan kota. Potensi yang dimiliki sebuah kota dimana potensi itu tidak ada di daerah lain, tentu akan menjadi kekuatan bagi kota tersebut untuk mempromosikan daerahnya. Seharusnya potensi sebuah kota harus mampu membangun image atau citra kota tersebut dibenak wisatawan. Di sinilah sebenarnya positioning akan terbangun.

Citra sebuah kota bisa muncul karena banyak faktor, seperti arti nama kota tersebut, simbol yang melekat pada kota terkadang dikaitkan dengan masa lalu, kota itu juga biasanya memiliki slogan yang terkait dengan sejarah kota. Citra kota dibangun berdasarkan semua yang kita pelajari tentang kota. Hal ini termasuk produk khas yang dihasilkan sebuah kota, bagaimana sebuah kota mengkomunikasikan dirinya secara baik dan bagaimana karakter umum warga kota yang tinggal di dalamnya (Yananda \& Salamah, 2014:148).

Produk khas yang dimiliki setiap daerah di Indonesia memiliki potensi yang besar untuk memajukan daerahnya, seperti keindahan alam, sumber daya bumi, pariwisata, budaya dan roda perekonomian. Jika potensi daerah telah tergali seiring proses promosi daerah yang baik, maka akan dapat menarik para investor dari dalam maupun luar daerah/ negeri. (https://www.mail-archive.com/ekonomisyariah@yahoogroups.com/msg05906.html)

Yananda dan Salamah (2014:65 dan 182) membangun citra kota harus dimulai dengan membangun identitas kota. Setiap kota pada dasarnya telah memiliki identitas yang tersimpan dalam memori kolektif kelompok yang menjadi pemangku kepentingan. Identitas adalah tampilan yang khas pada sebuah produk atau bahkan sebuah tempat. Bagi sebuah kota identitas ditunjukkan melalui infrastruktur, arsitektur, dan fasilitas kota. Selain itu identitas bisa ditunjukkan melalui seni, warga kota, kegiatan politik, dan fasilitas kota lainnya. Oleh karena itu dalam penelitian ini untuk melihat identitas Kota Tebing Tinggi digunakan pandangan Anholt tentang identitas kompetitif (competitive identity) sebagaimana telah jelaskan pada bagian sebelumnya.

1. Presence (keakraban orang mengenal kota).

Seperti telah dikemukakan pada sub bagian sebelumnya yang membahas persepsi masyarakat terhadap positioning Kota Tebing Tinggi, umumnya informan mengatakan bahwa Tebing Tinggi dikenal dengan kulinernya seperti lemang dan roti kacang.

Menurut Bagian Administrasi Humas Kota Tebing Tinggi (2012:12) mengatakan sebagai kota perlintasan, Tebing Tinggi memiliki beberapa makanan khas, salah satunya adalah lemang. Lemang produksi Kota Tebing Tinggi sangat terkenal lezat dan lemak. Karena kelezatannya itulah Kota Tebing Tinggi juga dijuluki sebagai Kota Lemang sampai tingkat regional dan nasional. Selain lemang, makanan khas lain dari Kota Tebing Tinggi adalah kue kacang. Kue kacang merupakan makanan yang baru muncul sekitar tahun 2005. Lemang dan kue kacang menjadi ikon kuliner Kota Tebing Tinggi.

2. Place (tampilan fisik kota meliputi kebersihan, kecantikan dan keindahannya)

Umumnya informan menyatakan bahwa kebersihan Kota Tebing Tinggi sudah baik, tetapi untuk keindahan dan kecantikan Kota Tebing Tinggi masih kurang dan perlu banyak yang harus dibenahi, seperti penghijauan yang dibuktikan dengan keberadaan pohon di jalan protokol yang masih minim. Tampilan ini menyebabkan Kota Tebing Tinggi terlihat gersang dan panas di saat siang hari. Kurangnya kecantikan Kota Tebing Tinggi juga disebabkan masih sedikitnya penerangan 
lampu seperti lampu hias yang berada di jalan protokol, sebagaimana pendapat informan saat peneliti wawancarai berikut :

"Tebing Tinggi bersih sehingga tampak kelihatan indah. Tidak bisa kita pungkiri keberhasilan Pak Umar membuat Tebing Tinggi ini indah. Tebing Tinggi ini nyaman, Tebing Tinggi ini tertib itu kita puji. Jadi Tebing Tinggi ini sudah cantik hanya kurang lighting (penerangan)" (Wawancara dengan M. Danil Sultan selaku Ketua Kadin Tebing Tinggi).

Persepsi terhadap tampilan fisik Kota Tebing Tinggi sesuai dengan pendapat Yananda \& Salamah (2014) yang menjelaskan akumulasi gambaran sebuah kota dibentuk berdasarkan pengalaman dan keterpaparan (exposure) dari hasil interaksi individu dengan kota. Ketika peneliti mendokumentasi keberadaan fisik Kota Tebing Tinggi, peneliti memperoleh lokasi yang memperlihatkan kebersihan Kota Tebing Tinggi sudah baik tetapi pohon penghijauan di median jalan masih kurang seperti di jalan Sudirman Kota Tebing Tinggi sekitar depan Rumah Sakit PTPN 3 Pamela dan jalan Yos Sudarso Kota Tebing Tinggi tepatnya di depan Terminal Bandar Kajum tidak jauh dari pintu masuk Selamat Datang Kota Tebing Tinggi.

Senada dengan pendapat Yananda \& Salamah di atas, Yoeti (2008) dalam Siallagan (2011:60) juga mengatakan bahwa keputusan untuk melakukan perjalanan lebih banyak menyangkut pemilihan daerah tujuan wisata. Pemilihan ini ditentukan oleh daya tarik yang terdapat di daerah yang akan dikunjungi. Daerah tujuan wisata yang memiliki daya tarik yang menarik akan meningkatkan jumlah permintaan objek wisata tersebut.

3. Potential (peluang ekonomi dan pendidikan)
Peluang ekonomi seperti membuka usaha dan peluang pendidikan di Kota Tebing Tinggi pada umumnya informan mengatakan peluang ekonomi di Tebing Tinggi ada meskipun beberapa informan juga berpendapat peluang usaha ada tetapi tidak dapat berkembang. BPS Kota Tebing Tinggi (2014:260) juga menjelaskan bahwa pada tahun 2013 sektor perdagangan, hotel dan restoran memberikan konstribusi sebesar 22,24\% kemudian sektor jasa pendidikan dan kesehatan memberikan kontribusi sebebsar $19,57 \%$.

\section{Pulse (gaya hidup kota)}

Gaya hidup yang ditampilkan Kota Tebing Tinggi, pada umumnya informan mengatakan kota sedang, kota menengah, kota tenang, kota nyaman dan kota berkembang. Menurut Damayanti (http://repository.petra.ac.id/15416/1/paperU AJY.pdf) mengatakan bahwa lifestyle atau gaya hidup adalah suatu perilaku yang diulang-ulang dalam kurun waktu tertentu menjadi suatu kebiasaan. Karena gaya hidup sangat berkaitan dengan keputusan dalam kegiatan keseharian dan budaya seseorang. Maka gaya hidup kota Tebing Tinggi dipersepsikan informan dengan kota sedang, kota menengah, kota tenang, kota nyaman dan kota berkembang merupakan persepsi yang dibentuk dari kegiatan keseharian informan ketika berinteraksi dengan kota.

5. People (kehangatan, keramahan, keterbukaan dan keamanan kota)

Dari data yang diperoleh umumnya informan mengatakan bahwa masyarakat (people) Tebing Tinggi terbuka dan ramah. Kemudian menyangkut masalah keamanan, mereka menilai Kota Tebing Tinggi sangat aman dan kondusif. Hal ini menjadi nilai utama bagi pemasaran Kota Tebing Tinggi sebagai daerah tujuan wisata. Sebagaimana Spillane (1987) dalam Siallagan (2011:59) mengemukakan bahwa kebutuhan dasar 
akan keamanan dan perlindungan harus disediakan dan juga keuletan serta keramahtamahan tenaga kerja wisata perlu dipertimbangkan supaya wisatawan merasa aman dan nyaman selama perjalanan wisata.

Demikian pula Yananda \& Salamah (2014:218) mengatakan warga kota yang hangat dan menggairahkan menjadi daya tarik tersendiri. Kota dengan warga kota yang "ramah" dan "kasar" dipersepsikan secara berbeda. Sebagian orang membangun persepsi terkait suatu kota berdasarkan kehangatan warga kota. Kota yang dianggap lebih hangat dan merangsang kegairahan beraktivitas akan mendapatkan persepsi positif.

6. Prerequisites (standar harga kebutuhan hidup dan kelengkapan fasilitas publik)

Umumnya informan mengatakan bahwa harga kebutuhan di Kota Tebing Tinggi dikategorikan murah dari kota - kota yang ada di Provinsi Sumatera Utara. Situasi harga kebutuhan murah ini tentu dapat mengundang dan memikat wisatawan datang ke Kota Tebing Tinggi untuk menikmati makanan atau kulinernya, souvenirnya, transportasinya dan sebagainya. Karena kecenderungan konsumen akan melakukan penghematan untuk pengeluarannya dan bertindak secara rasional sebagaimana pendapat Yoeti (2008) dalam Siallagan (2011:9) mengatakan terdapat tiga tingkah laku konsumen (consumer behaviour) dalam memenuhi kebutuhan terhadap barang dan jasa (goods and services) yaitu: keterbatasan pendapatan (income), melakukan pembelian dengan bertindak secara rasional, ingin mencapai kepuasan (to maximize their total satisfaction).

Untuk kelengkapan fasilitas publik di Kota Tebing Tinggi rata-rata informan mengatakan sudah ada tetapi belum memadai atau belum maksimal, seperti hotel (penginapan) berbintang yang tidak ada, jalan di inti kota yang sempit, halte bus yang masih kurang, peralatan kesehatan rumah sakit umum daerah yang masih kurang lengkap. Fasilitas kelengkapan publik yang belum memadai ini tentu akan mengganggu daya pemasaran daerah.

Menurut Spillane (1987) dalam Siallagan (2011:59) selama tinggal ditempat tujuan wisata, wisatawan memerlukan tidur, makan dan minum oleh karena itu sangat dibutuhkan fasilitas penginapan. Ketersediaan fasilitas dilokasi wisata akan membuat wisatawan merasa nyaman untuk lebih lama lagi dalam melakukan perjalanan wisata. Oleh karena itu Yananda \& Salamah (2014:218) mengatakan kota yang menyediakan kelengkapan fasilitas produk dan jasa terlalu mahal akan dihindari untuk didatangi. Kota yang memiliki kelengkapan fasilitas terbatas akan lebih dihindari karena diasumsikan belum memiliki kelayakan. Maka kota penting untuk mempertahankan harga yang wajar untuk kebutuhan sehari hari dan selalu tersedia pasokannya.

Berdasarkan identitas Kota Tebing Tinggi yang telah dikemukakan para informan di atas memberikan gambaran kemampuan dan kekuatan Kota Tebing Tinggi untuk mempromosikan dan memasarkan kotanya. Identitas tersebut akan mendukung potensi yang dimiliki Kota Tebing Tinggi karena pada umumnya potensi daerah yang memiliki nilai jual berasal dari aset wisata di daerah tersebut.

Setiap daerah mempunyai potensi dalam mengembangkankan pariwisata daerahnya masing - masing yang dilihat dari sisi tempat wisata, sejarah daerahnya, ataupun dengan produk-produk cinderamata khas yang menjadi ikon daerah tersebut (http://thesis.umy.ac.id/datapublik/t21911.pd f).

Hasil FGD dan wawancara para informan umumnya mengatakan potensi unggulan yang dapat menjadi positioning Kota Tebing Tinggi adalah kuliner dimana pendapat mereka didasarkan pada posisi 
Kota Tebing Tinggi yang strategis yaitu berada di titik persimpangan lintas barat dan lintas timur jalur Sumatera serta perlintasan menuju daerah wisata Danau Toba, kemudian Kota Tebing Tinggi hanya membutuhkan waktu perjalanan darat lebih kurang 2 (dua) jam dari Kota Medan. Hal ini sesuai dengan hasil penelitian Saragih (2013:168) bahwa yang diinginkan pengunjung agar mau mengunjungi daerah adalah daerah tersebut memiliki ciri khas tersendiri, apakah dari budayanya, kulinernya, obyek wisatanya dan sebagainya. Dimana hasil penelitiannya mengungkapkan saat ini yang dimiliki Kota Binjai adalah kuliner.

Dari hasil penelitian Sari (2015) misalnya, mengatakan bahwa letak geografis Kota Batu menjadi keunggulan utama yang dimanfaatkan Kota Batu dalam mendukung sektor pariwisatanya. Demikian juga pendapat Yoeti (2008) dalam Siallagan (2011:51) bahwa aksesibilitas ke daerah tujuan wisata yang akan dikunjungi banyak mempengaruhi pilihan wisatawan, wisatawan menginginkan tersedianya macam-macam transportasi yang dapat digunakan dengan harga yang bervariasi. Karena biaya transportasi akan mempengaruhi biaya perjalanan secara keseluruhan.

Meskipun dalam jumlah kecil informan mengatakan Kota Tebing Tinggi tidak memiliki potensi yang dapat ditonjolkan dan menjadi nilai jual kepada para wisatawan. Persepsi mereka tersebut dilatar belakangi dari pengalaman dan keterpaparan mereka terhadap Kota Tebing Tinggi yang tidak memiliki objek wisata alam natural.

Dari persepsi informan mayoritas mengatakan realisasi Kota Tebing Tinggi sebagai kota jasa sesuai RPJMD dapat diwujudkan dengan wisata kuliner. Kemudian presence atau orang mengenal Kota Tebing Tinggi dalam pendapat informan rata-rata mengatakan Tebing Tinggi dikenal dengan kulinernya seperti lemang, roti kacang dan mie rebus bang Tambi. Hal demikian sesuai dengan pencapaian prestasi Pemerintah Kota Tebing Tinggi yang meraih rekor MURI lemang dengan 96 rasa pada tahun 2013 dalam rangka menyambut Hari Ulang Tahun Kota Tebing Tinggi yang ke-96 tahun (http://sumutpos.co/lemang-besar-96-rasaakan-disuguhkan-untuk-masyarakat/). Tentu peraihan rekor MURI tersebut merupakan realisasi menuju wisata kuliner.

Kemudian ketika FGD, Gul Bakhri Siregar mengatakan bahwa beliau melalui browsing di internet pernah melihat youtube yang menampilkan sebuah acara Deli TV dengan program Jalan Nyasar Episode 9 yang judulnya "Ter Muter Tebing Tinggi", berikut kutipan pendapat beliau :

"Saya kemarin buka youtube cari cari apa saja sih yang sudah diupload orang tentang Tebing Tinggi. Tiba tiba terlihatlah oleh saya satu program yang dibuat judulnya jalan - jalan kesasar. Ditanya reporter tadilah satu masyarakat, Tebing Tinggi ini apa yang bisa dilihat ? Masyarakat tadi menjawab di Tebing Tinggi ini tidak ada apa - apanya pak. Tidak ada yang bisa dilihat disini. Tetapi begitu pun si reporter tadi tidak langsung menyerah. Ditelusurinya Tebing Tinggi ini ternyata dia dapatkan rumah - rumah peninggalan datuk - datuk yang ada di Bulian sana, sampai ke peninggalan rumah Tuan Syech Beringin. Kemudian pemakaman-pemakaman datuk Bandar Kajum”.

Ketika peneliti melihat program tersebut di youtube pada tanggal 15 Agustus 2015, di dalamnya disajikan segala potensi yang ada di Kota Tebing Tinggi. Pada awalnya, ketika presenter acara tersebut menanyakan potensi yang dimiliki Kota Tebing Tinggi kepada masyarakat, ternyata mereka mengatakan tidak ada apa - apa di 
Tebing Tinggi. Namun karena nama program acaranya Jalan Nyasar, maka presenter dan tim menelusuri setiap sudut yang ada di Tebing Tinggi.

Dari penelusurannya, ternyata ada beberapa tempat yang dapat dijadikan potensi unggulan wistata di Kota Tebing Tinggi, yaitu Istana Tengku Hasyim dan Pusara Kerajaan Padang yang berada di Jalan Kapten Pierre Tendean Kota Tebing Tinggi. Kerajaan Padang tersebut merupakan kerajaan yang bercorak melayu. Kemudian Mesjid Raya Nur Addin dimana di halaman mesjid tersebut terpampang Silsilah Kerjaaan Padang yang di dalamnya terdapat nama Tengku Hasyim atau nama Raja Kerajaan Padang. Di Kecamatan padang Hilir terdapat peninggalan Rumah Syech Beringin, seorang ulama sufi yang ikut berjuang mempertahankan kemerdekaan Republik Indonesia dari bangsa Jepang yang dikenal dengan peristiwa 13 Desember 1945. Namun dalam tayangan tersebut rumah itu tampak telah rusak.

Acara Deli TV program Jalan Nyasar Episode 9 juga memberikan informasi bahwa potensi unggulan Kota Tebing Tinggi di luar dari cagar budaya adalah kuliner. Kuliner atau makanan ciri khas Kota Tebing Tinggi adalah Lemang Batok yang berada di Jalan Chong Api depan Mesjid Raya Nur Addin. Dikatakan Lemang Batok karena memasaknya menggunakan arang pembakarannya dari tempurung kelapa dan lemang Tebing Tinggi dimakan bersama srikaya. Kemudian kuliner malam di Pajak Bunga yang terkenal adalah Mie Rebus Bang Tambi dan anaka kerang rebus.

Persepsi informan yang umumnya mengatakan potensi Kota Tebing Tinggi adalah kuliner sama dengan hasil penelusuran acara Jalan Nyasar dimana hasil penelusuran mereka mengungkapkan bahwa potensi Kota Tebing Tinggi diantaranya adalah kuliner. Kemudian Bagian Administrasi Humas Tebing Tinggi
(2012:21-22) mengatakan kuliner malam berada di ruas jalan Mas Tirtodarmo Haryono atau dikenal dengan daerah Pajak Bunga Kelurahan Pasar Gambir Kecamatan Tebing Tinggi Kota, seperti mie bang Tambi. Kemudian kuliner lainnya yang terkenal selain lemang dan roti kacang adalah restoran india, waroeng poejok dan mie tek-tek.

Berdasarkan persepsi masyarakat terhadap positioning Kota Tebing Tinggi yang mengatakan positioningnya adalah kota jasa yang dikhususkan kepada jasa tertentu, kemudian bila dilihat dari potensi unggulan yang dimiliki Kota Tebing Tinggi adalah kuliner, maka positioning Kota Tebing Tinggi adalah "Kota Jasa Wisata Kuliner".

Lemang dan roti kacang yang umumnya dipersepsikan oleh informan dalam presence (keberadaan) Kota Tebing Tinggi yang dikenal orang, menunjukkan citra Kota Tebing Tinggi sebagai kota kuliner yang harus dipasarkan secara baik. Sebagaimana pernyataan Walikota Tebing Tinggi Umar Zunaidi Hasibuan dalam Harian Analisa (2015) pada momentum pemecahan rekor Museum Rekor Indonesia (MURI) makan soto terbanyak mengatakan bahwa makan soto terbanyak ini nantinya akan menjadi implementasi Kota Tebing Tinggi menjadi kota kuliner khususnya soto ternikmat dan terlezat. Tebing Tinggi harus bisa menjadi tujuan bagi pelintas yang akan singgah, terutama pada bidang kulinernya seperti soto, roti kacang dan lemang.

Undang Undang Republik Indonesia Nomor 10 Tahun 2009 tentang kepariwisataan menyebutkan bahwa salah satu usaha pariwisata adalah jasa makanan dan minuman (kuliner). Kemudian secara rinci Suryadana (2009:20) menjelaskan wisata kuliner adalah wisata yang menyediakan berbagai fasilitas pelayanan dan aktivitas kuliner yang terpadu untuk memenuhi kebutuhan wisatawan yang 
dibangun untuk rekreasi, relaksasi, pendidikan dan kesehatan, dimana daya tarik wisata kuliner tersebut didukung di antaranya dari lokasi yang nyaman dan bersih, harga dan proporsi nilai, suasana kekeluargaan, dan lingkungan yang menarik.

Persepsi para informan yang umumnya mengatakan bahwa Tebing Tinggi, kotanya bersih, harga kebutuhannya relatif murah, masyarakatnya terbuka dan ramah, aman dan terletak pada posisi strategis yakni berada di titik pertemuan lintas timur dan lintas barat serta kota perlintasan menuju daerah wisata Parapat (Danau Toba), tentu ini sesuai dengan pendapat Suryadana di atas untuk menjadi daya tarik wisatawan, kemudian juga menjadi atribut atau karakteristik positioning Kota Tebing Tinggi sebagai kota jasa wisata kuliner.

Atribut merupakan nilai diferensiasi atau yang membedakan dengan daerah lainnya. Sebagaimana Myers (1996) dalam Morissan (2012:73) mengatakan diferensiasi merupakan tindakan yang dilakukan bersifat lebih rasional yaitu tidak ingin unggul dalam segala hal, tetapi membatasinya pada satu atau beberapa segi saja yang superior dibanding para pesaingnya.

Analisa positioning Kota Tebing Tinggi sebagai kota jasa wisata kuliner beradasarkan pendapat Kartajaya (2007), dapat diuraikan sebagai berikut:

1. Kota jasa wisata kuliner merupakan hasil dari persepsi masyarakat yang dalam hal ini adalah stakeholders Kota Tebing Tinggi, sehingga mendeskripsikan nilai unggulan dari Kota Tebing Tinggi.

2. Kota jasa wisata kuliner memiliki keunggulan kompetitif dengan daerah lainnya karena Tebing Tinggi berada di posisi yang strategis.

3. Kota jasa wisata kuliner dalam penelitian ini dapat dikatakan unik, hal ini dibuktikan dengan lemang yang dimakan pakai srikaya dan roti kacang yang gurih tidak sama dengan bakpia Jogja.

4. Kota jasa wisata kuliner relevan dengan perkembangan jaman.

Positioning merupakan bagian dari komunikasi promosi dan pemasaran. Keberhasilan promosi dan pemasaran terhadap suatu produk bergantung dengan tampilan sajian positioning yang tepat. Menurut Hermawan (2012:39) pembentukan citra yang positif dapat dilakukan dengan iklan atau promosi yang memiliki karakteristik tertentu yang tidak dapat dimiliki oleh strategi pemasaran lainnya. Bisa saja dilakukan dengan cara menciptakan suatu produk yang memiliki poin lebih, karakteristik unik, atau mempunyai manfaat lebih yang dapat menjadi citra positif dihadapan konsumen. Jika hal ini dapat dilakukan maka citra positif yang berkembang di masyarakat akan terbentuk dan mendatangkan beberapa faktor positif untuk mendongkrak penjualan.

Untuk selanjutnya positioning yang dimiliki daerah selain untuk dipromosikan, juga untuk dipasarkan. Pengertian pemasaran daerah dapat diartikan sebagai suatu proses untuk menciptakan kondisi daerah sedemikian rupa sehingga para produser, perusahaan, investasi asing, eksportir, wisatawan bahkan penduduk merasa nyaman di dalamnya. Dengan kata lain, pemasaran daerah dapat diartikan sebagai upaya menarik investasi swasta, pedagang maupun turis dalam mewujudkan rencana daerah dengan penerapan konsep konsep pemasaran (Siregar, 2012).

Persepsi masyarakat terhadap positioning Kota Tebing Tinggi dan potensi unggulan yang dimiliki Kota Tebing Tinggi sebenarnya menjadi kajian penting untuk menjadi positioning Kota Tebing Tinggi karena pada hakikatnya positioning adalah janji yang diberikan daerah dan dapat 
dibuktikan. Ketika persepsi masyarakat mengatakan positioning Kota Tebing Tinggi adalah kota jasa wisata kuliner maka sesungguhnya kuliner harus menjadi prioritas utama perhatian pemerintah kota. Sebagaimana pendapat Kartajaya \& Yuswoady (2005) dalam Helmi (2007:120) kemampuan daerah memenuhi janji kepada pelanggannya akan menentukan kepercayaan dan kredibilitas. Semakin daerah mampu memenuhi janji tersebut, semakin tinggi pula kepercayaan dan kredibilitas di mata pelanggan dan akhirnya semakin kokoh pula positioningnya di benak pelanggan.

\section{KESIMPULAN}

Persepsi masyarakat terhadap positioning Kota Tebing Tinggi adalah kota jasa. Persepsi ini dibentuk berdasarkan pengalaman, pengetahuan dan keterpaparan. Persepsi informan terhadap positioning Kota Tebing Tinggi dikaji dengan melihat realisasi mewujudkan kota jasa sebagaimana yang telah dijelaskan dalam RPJMD meliputi pergudangan, industri, terminal peti kemas, wisata budaya dan wisata kuliner. Kemudian sosialisasi yang dilakukan Pemerintah Kota Tebing Tinggi dalam mensosialisasikan Tebing Tinggi sebagai kota jasa dan melihat presence orang mengenal Kota Tebing Tinggi.

Potensi keunggulan yang dapat menjadi positioning Kota Tebing Tinggi adalah kuliner yang meliputi lemang, roti kacang dan soto. Namun untuk lemang diperlukan perbaikan dan peningkatan dari segi kualitasnya sehingga dapat memiliki nilai jual. Identitas Kota Tebing Tinggi yang menampilkan suasana aman dan nyaman dan karakter masyarakatnya yang ramah dan terbuka menjadikan Tebing Tinggi memiliki potensi untuk menjadi kota jasa wisata kuliner.
Dari persepsi masyarakat terhadap positioning Kota Tebing Tinggi dan potensi unggulan yang dimiliki Kota Tebing Tinggi, maka hasil penelitian ini menyatakan positioning Kota Tebing Tinggi adalah kota jasa wisata kuliner yang didukung dengan posisi kotanya yang terletak pada posisi strategis seperti yang telah diuraikan sebelumnya.

\section{DAFTAR PUSTAKA}

Amar. (2009). Identitas Kota, Fenomena Dan Permasalahannya. Jurnal "ruang" Volume 1 Nomor 1 September 2009 Universitas Tadulako.

Badan Pusat Statistik (BPS) Kota Tebing Tinggi. (2014). Tebing Tinggi Dalam Angka (Tebing Tinggi In Figures) 2014. Tebing Tinggi: BPS Kota Tebing Tinggi bekerja sama Bappeda Kota Tebing Tinggi.

Bagian Administrasi Humas, Pimpinan dan Protokoler Kota Tebing Tingg. (2012). One Village One Product. Tebing Tinggi: Bagian Adm. Humas PP Kota Tebing Tinggi.

Belch, George E. \& Michael A. Belch. (2001). Advertising and Promotion An Integrated Marketing Communications Perspective Fifth Edition. Boston: McGraw-Hill

Bungin, Burhan. (2011). Penelitian Kualitatif Komunikasi, Ekonomi, Kebijakan Publik, dan Ilmu Sosial Lainnya. Jakarta: Kencana Prenada Media Group

Gunawan, Imam. (2013). Metode Penelitian Kualitatif Teori dan Praktik. Jakarta: Bumi Aksara

Hasibuan, Umar Zunaidi. (10 Agustus 2015). Pecahkan Rekor Muri Makan Soto Terbanyak. Harian Analisa. 
Helmi, Syafrizal. (2007). Regional Branding : Strategi Memasarkan Daerah. Wahana Hijau Jurnal Perencanaan \& Pengembangan Wilayah, Vol.2, No. 3, April 2007.

Kusmanto, H., (2015). Persepsi Masyarakat Terhadap Upaya Kepala Kelurahan Sebagai Salah Satu Unsur Pelaksana Pemerintahan Kota Medan, Jurnal Ilmu Pemerintahan dan Sosial Politik, 3 (1): 49-57.

Hermawan, Agus. (2012). Komunikasi Pemasaran. Jakarta: Erlangga

Kartajaya, Hermawan. (2007). On Positioning (seri 9 elemen marketing). Bandung: Mizan dan MarkPlus\&Co

Kasali, Rhenald. (2000). Membidik Pasar Indonesia Segmentasi, Targeting dan Positioning. Jakarta: Gramedia Pustaka Utama

Lubis, Lusiana Andriani. (2012). Pemahaman Praktis Komunikasi Antarbudaya. Medan: USU Press.

Moleong, Lexy J. (2006). Metodologi Penelitian Kualitatif Edisi Revisi. Bandung: Remaja Rosdakarya.

Morissan, (2013). Teori - Teori Komunikasi Individu Hingga Massa. Jakarta: Kencana Prenada Media Group. (2012). Periklanan Komunikasi Pemasaran Terpadu. Jakarta: Kencana Prenada Media Group.

Mulyana, Deddy. (2007). Ilmu Komunikasi Suatu Pengantar. Bandung: Remaja Rosdakarya

Nawar, Hanafiah Daniel., Sirojuzilam. dan Suriadi, Agus. (2006). Analisis Daya Saing Ekspor Minyak Kelapa Sawit Provinsi Sumatera Utara. Jurnal Studi Pembangunan. Volume 2, Nomor 1. ISSN 0216-9339. Oktober 2006.

Olsson, Anna \& Catalina Sandru. (2006). The Brand Proposition Positioning \&
Building Brand Personality. Bachelor Thesis. Luleå-Sweden: Luleå University of Technology.

Peraturan Daerah Kota Tebing Tinggi Nomor 3 Tahun 2012 Tentang Rencana Pembangunan Jangka Menengah Daerah (RPJMD) Kota Tebing Tinggi Tahun 2011-2016. Tebing Tinggi: Pemerintah Kota Tebing Tinggi.

Ries, Al \& Jack Trout. (2002). Positioning :

The Battle For Your Mind. Edisi ulang tahun. (Bertha Lucia, Terjemahan). Jakarta: Salemba Empat.

Santoso, Eko Budi. (2010). Inovasi Dalam Riset Dan Praktek Perencanaan Menuju Penataan Ruang Kota Masa Depan. Makalah Seminar Nasional Perencanaan Wilayah dan Kota. Surabaya: ITS.

Saragih, Nila Kesuma. (2013). Perencanaan City Branding Kota Binjai Dalam Mendukung Daya Saing Daerah. Tesis tidak dipublikasikan. Bandung: Sekolah Tinggi Ilmu Administrasi Lembaga Administrasi Negara.

Sitanggang, M.D., dan Suadi H., (2014). Persepsi Masyarakat Terhadap Kinerja Camat Dalam Meningkatkan Mutu Pendidikan, Jurnal Ilmu Pemerintahan dan Sosial Politik, 2 (1): $58-77$

Sari, Ismi Mutia. (2015). Analisis Implementasi City Branding : Studi Pada Kota Batu - Jawa Timur. Jurnal Ekonomi. Malang: Universitas Brawijaya.

Siallagan, Anthony Fransisko. (2011). Analisis Permintaan Wisatawan Nusantara Objek Wisata Batu Kursi Siallagan, Kecamatan Simanindo, Kabupaten Samosir. Skripsi. Semarang: Universitas Diponegoro.

Siregar, Anwar Sadat. (2012). Strategi Regional Branding Kabupaten 
Padang Lawas Utara. Tesis tidak dipublikasikan. Medan: USU

Suryadana, Moh. Liga. (2009). Perkembangan Industri Makanan (Kuliner). Makalah Seminar Sehari CREPS. Bandung: Universitas Pendidikan Indonesia.

Vincent, Gaspersz. (1997). Manajemen Bisnis Total Dalam Era Globalisasi. Jakarta: PT. Gramedia.

Wardhani, Andy Corry. (2011). Corporate and Marketing Communication. (Irwansyah \& Heri Budianto, Ed.). Jakarta: Buku Litera

West, Richard \& Lynn H. Turner. (2008). Pengantar Teori Komunikasi Analisis dan Aplikasi. Ahli Bahasa Maria Natalia Damayanti Maer. Jakarta: Salemba Humanika.

Yananda, M. Rahmat \& Ummi Salamah. (2014). Branding Tempat Membangun Kota, Kabupaten, dan Provinsi Berbasis Identitas. Jakarta: Makna Informasi.

\section{Publikasi Elektronik :}

http://www.kemendagri.go.id/article/2013/0 4/12/city-branding-untuk-pemdaperlukah (diakses tanggal 5 Maret 2015).

https://www.youtube.com/watch?v=CrHZA 6woU0M (Jalan Nyasar Episode 9 Termuter Tebing Tinggi - Seg 1/4 diakses tanggal 15 Agustus 2015)

http://thesis.umy.ac.id/datapublik/t21911.pdf (diakses tanggal 16 Agustus 2015) http://sumutpos.co/lemang-besar-96-rasaakan-disuguhkan-untuk-masyarakat/ (diakses tanggal 16 Agustus 2015. https://www.mail-archive.com/ekonomi syariah@yahoogroups.com/msg05906 .html, (diakses tanggal 16 Agustus 2015). http://repository.petra.ac.id/15416/1/paper_ UAJY.pdf (diakses tanggal 09 September 2015). 